also computing machinery. The moral is that the Reagan Administration should now be bending its efforts to devising a system for a strategic embargo in which forbidden exports are classified not by type and catalogue number but by the effort in research and development that would be required to turn them into militarily useful weapons. On past experience, the United States would be chancing its arm by aiming at an advantage in time of three years or thereabouts. Does the present administration have the courage to acknowledge that that is about the best that can be hoped for?

\section{Blow cold, blow hot}

\section{$A$ relaxation of austerity has benefited the British scientific enterprise; but strings are attached.}

The conclusion that the British Secretary of State for Education and Science, Sir Keith Joseph, may in reality be a better minister than he likes it to be thought emerged earlier this week from the Chancellor of the Exchequer's forward look at public spending in the three years immediately ahead. Sir Keith seems to have won from the Treasury an extra $£ 2$ million, or 0.4 per cent, of the budgets of the research councils in the financial year immediately ahead (beginning on 1 April next year). But since, unexpectedly, it has become known that an extra $£ 4$ million will be spent next year on the British Antarctic Survey, there is no way of telling whether the Natural Environment Research Council (the survey's sponsor) will be deprived of a further $£ 2$ million. Plainly, all departments of state in the British government are still fighting the Falklands war (which is not to say that the Antarctic survey will not put the extra funds fallen into its lap to good use).

The more valuable component of the science budget for next year, as now amended by the British Treasury, is what was being said earlier this week about the special support to enable universities to recruit young people to academic posts. Sir Keith has already stolen $£ 6$ million from the budget of the Social Science Research Council for this purpose, but when that will become available is to some extent in the hands of the research council itself. Now the intention is that up to $£ 10$ million should be spent on the recruitment of talented people (mostly in the sciences) to posts in the universities. For the time being, the fact that it is by no means clear how the extra money will be spent will not shade the joy with which university campuses will be suffused. For the best part of a decade, British universities have been unable to recruit to their teaching staffs the talented people whom, in other times, they would have snapped up. Even the most secure among older academics now acknowledge their need of "young blood". So, it should be said, they should have donc some time ago.

Apart from the uncertainty about the source of this extra money, and its duration, the only difficulty in what the Department of Education and Science was saying this week after the Chancellor's declaration was that some of the extra money to be channelled towards the universities will be spent on courses in information technology. Apparently Sir Keith Joseph has been listening to Mr Kenneth Baker, the minister of state at the Department of Industry with special responsibility in this field. While $\mathrm{Mr}$ Baker is dangerously oversold on this government's plan to install cable television in Britain any day now (see Nature 28 October, p.765), he is right to be plugging the virtues of the technology of information. The open question, which Sir Keith Joseph should be brooding about, is whether it is right (let alone proper) for the Department of Education and Science to be telling universities that they can have extra money provided that they toe some ministerially determined line. In their hearts they know they should resist, and collectively refuse the money. In their boots, they know there are enough among them who will accept to undermine whatever high-minded position the high-minded among them might adopt. In short, the universities are being told that there will be graduate courses on information technology even if individual universities see no need of them. Sir Keith's success in persuading the Chancellor of the Exchequer may, in other words, have designed a poisoned chalice for them all.

\section{Do not foretell the future}

\section{The European Commission's futures research \\ project has not seen the future; but nobody can.}

In Brussels, FAST means "forecasting and assessment in the field of science and technology", and the European Community now has two substantial volumes of a report on the subject. Among the now copious literature of the future, the report stands out for its sanity - the guiding assumption is that there must be a way in which present economic troubles can be cured by intelligent research, development and capital investment. The document is also full of interest - there is an intelligent discussion of the changing pattern of employment under the influence of changing technology and of what the authors of the report repeatedly call "the international division of labour", usually in a European context. Moreover, recommendations as to where, in the whole field, research and development should be encouraged are not pulled like rabbits out of a hat but are, rather, preceded by a careful account of the present problems of European industries, from chemicals to construction. For all these virtues, however, the report is too disjointed to be persuasive. Worse still, it is unlikely to be the kind of touchstone for planning the future development of the European Community's research programme that the Commission hoped for when the work was set in hand three years ago.

The reasons for this disappointment are easily found, and are probably inescapable in any attempt such as this to foretell the future. First, the forecast provided, necessarily a projection of the present into future decades, is innocent of the surprises yet to come. In this spirit, the FAST report pays particular attention to two now fashionable fields in which technology is likely to have a profound effect on the character of society - information technology and biotcchnology. Thus the report has much in common with other recent attempts to plan ahead in research and development, the attempt by a committee of the British Department of Industry to map out a programme of research and development in information technology, for example. Thus, while some seers have for years been prophesying that biotechnology will be important, it is less than ten years since the prospect became as substantial as it is now. Nobody can be blamed, but even the specific account of the future now offered must overlook the technologies that have not yet emerged. A further snag is that committees are now well placed to plan the future strategy of research. Yet while committees have been saying for the past thirty years that the closing decades of this century would be dominated by the technology of telecommunications and computers, it has never previously been possible to spell out just how a government or a corporation should seek to profit from the likely course of development.

For such reasons, it is to be hoped that the European Community as a whole will take most to heart those features of the report now published that deal with structural questions, not the details of which research and development projects are likely to be most valuable in the years ahead. First, there is an urgent need for more incentives, within the Community, for a rational division of labour that will allow the most efficient producers to produce most. Although there has recently been some progress in throwing public purchasing open to all European companies, governments are still able to drag their feet in the interests of chauvinism - and as a result undermine their own long-term prosperity. Similarly, there is an urgent need somehow to make the European system of higher education and technical training more flexible, and to encourage mobility within it. Here again, chauvinism, if not outright xenophobia, is still all too common within Europe. But would it not make great sense that Europe should, for example, work towards some common university system? On both counts, alas, the obvious objection is that if some nations gained from a more efficient division of labour, others would lose. The answer is that this is not a "zero-sum game" but one in which the wealth of Europe as a whole would be improved. 